\title{
Strength and Workability Assessment of Concrete Produced by Partial Replacement of Cement with Waste Clay Bricks
}

\author{
Nwankwo E. ${ }^{1, *}$ and John A. T. ${ }^{1}$ \\ ${ }^{1}$ Department of Civil Engineering, University of Benin, Benin City, Nigeria \\ *Corresponding Author: ebuka.nwankwo@uniben.edu
}

https://doi.org/10.36263/nijest.2019.02.0137

\begin{abstract}
The use of waste clay bricks - which are abundant in the Niger Delta Region of Nigeria - as supplementary cementitious material, would enable the construction industry utilize thousands of tons of brick blocks that would have ended up as waste or landfill materials. This paper establishes the pozzolanic properties of these waste clay bricks in terms of strength and workability. Waste clay brick powders are introduced as partial replacement for cement in this research. All tests were done in accordance with relevant British Standards. It was observed that waste clay brick, as an admixture, increases the workability and consistency of fresh concrete. Also, an 11 percent increase in compressive strength was observed with a 10 percent partial replacement of cement with waste clay brick powders. An equation is developed to capture the marginal increase in compressive strength of concrete produced with waste clay bricks, even after 28 days, for a 10\% partial replacement of cement.
\end{abstract}

Keywords: Cement, Strength, Compression, Aggregate and Regression.

\subsection{Introduction}

To preserve the environment, attempts have been made to employ waste materials in the production of concrete and in the construction of cost-effective housing. Proper utilization of discarded or waste materials in concrete production results in less expensive concrete and also offers a cost-effective ecological solution to waste management and disposal (Bahoria et al., 2013).

Concrete comprises of cement, aggregates and water (Devi and Gnanavel, 2014 and Naik, 2008) with cement as the binder material and the most expensive component. Cement production emits a green-house gas known as carbon dioxide $\left(\mathrm{CO}_{2}\right)$. Imbabi et al (2012) estimated that cement production contributes $5 \%$ of the global green-house gas emissions. However, more recent works estimates that the total $\mathrm{CO}_{2}$ produced by the production of cement clinkers and the combustion of fossil fuel required to heat raw materials during cement production could contribute to as much as $8.6 \%$ of global $\mathrm{CO}_{2}$ emission (IEA, 2007 Miller et al, 2016). To manage the environmental effects of concrete production, modern techniques such as using milled brick blocks as an admixture or applying it directly to replace a portion of cement has become common practice and broadly viewed as acceptable in concrete works. It is important to note that supplementary cementitious materials reduce the amount of cement in concrete and thus reduces concrete's susceptibility to cracking, heat generation and carbon dioxide emission.

Research has confirmed the viability of certain construction waste products as suitable for use as supplementary cementitious materials, such as silica fume, blast furnace slag, fly ash, foundry sand, palm oil clinker (Rashad, 2016; Valcuende et al., 2015; Imbabi et al., 2012; Prabhu et al., 2014). These supplementary materials are grounded and heated to controlled temperatures to produce blended cements with improved economic and physical properties (Detwiler et al., 1996). 
Elinwa et al (2005) reported that the use of sawdust ash or wood ash as partial substitute in the matrix for mortar and concrete work not only acts as an economic substitute but also a reliable disposal method of said waste.

Ranjodh et al. (2013) reported that brick dust can be used effectively to develop good quality selfcompacting fresh concrete with satisfactorily slump and setting time. The hardened properties of the self-compacting concrete improved daily till 28 days because of greater hydration of cement. Nassar and Soroushian (2012) reported that the chemical composition of glass powder makes it comparable to other cementitious materials. Hemraj and Kumavat, (2013) examined brick waste and inferred that it performs as a pozzolana and his results show that richer mixes give lower value of bulk density and higher values of compressive strength at replacement level up to $40 \%$ of sand, his findings contribute to the minimizing the impact waste using eco-efficient resources. Hasanpour (2013) also examined the possibility of using bricks powder/dust as replacement until $40 \%$, he further established in his findings that although concrete developed may suffer slightly a loss in strength, his research confirmed brick powder has the potential to serve as pozzolana. The performance of grinded brick blocks powder in concrete works was researched experimentally.

Some recent studies have attempted to investigate the pozzolanicity of clay bricks. Ulukaya and Yüzer (2016) examined the pozzolanicity of clay fired bricks using direct and indirect methods. Their investigation revealed that clay treated at $850^{\circ} \mathrm{C}$ can be regarded as the best pozzolan, and the pozzolanicity of clay bricks significantly changes the mechanical properties of crushed brick-lime mortars. Bediako (2018) examined that optimum cement replacement in concrete, where cement is replaced with Ground Waste Clay Bricks (GWCB. Bediako (2018) observed that compressive strength results indicated that the optimum Portland cement replacement with Ground Waste Clay Bricks (GWCB) was at 30 wt.\%.

Bricks, when milled to powder, can serve as a supplementary cementitious material, although it has not yet acclaimed the same status commercially (Rashed, 2014). Thus, this work attempts to investigate the pozzolanic properties of waste brick blocks, especially those produced with clays from Bayelsa State, Nigeria.

\subsection{Materials and Method}

\subsection{Materials}

The materials used in this study are Portland cement, ground waste clay brick, aggregates, water. The Portland cement was a type I/II cement and Table 1 shows the chemical composition of the cement used in this research. The clay bricks, which were used as refractory surfaces for decommissioned kilns, were obtained in waste dumps in Bayelsa State but were manufactured in Warri, Delta states, using local clays. Table 2 shows the chemical composition of the waste brick clays used in this research. The studied potential pozzolan meets the ASTM C618 (ASTM, 2015) recommendation that for a suitable pozzolan, the summation of the $\mathrm{SiO}_{2}, \mathrm{Al}_{2} \mathrm{O}_{3}$ and $\mathrm{Fe}_{2} \mathrm{O}_{3}$ must not be less than $70 \%$.

The waste clay bricks obtained for this research were crushed to dust and processed into powdered form (see Figure 1). The aggregates (fine and coarse) used were obtained from the Wilberforce Islands in Bayelsa State in accordance with British Standards BS EN 12620:2013 (BSI, 2013). The maximum size of the coarse aggregate was $20 \mathrm{~mm}$. Clear portable water free from all harmful and extraneous matter was used for all the experiments as specified by the British Standards BS EN 1008:2002 (BSI, 2002). 
Table 1: Major components of cement (Oriji and Dulu, 2015)

\begin{tabular}{ll}
\hline Oxide & Weight \% \\
\hline $\mathrm{CaO}$ & $59.60 \%$ \\
$\mathrm{Fe}_{2} \mathrm{O}_{3}$ & $3.22 \%$ \\
$\mathrm{SiO}_{2}$ & $20.62 \%$ \\
$\mathrm{Al}_{2} \mathrm{O}_{3}$ & $6.01 \%$ \\
$\mathrm{MgO}$ & $3.65 \%$ \\
$\mathrm{SO}_{3}$ & $2.46 \%$ \\
$\mathrm{~K}_{2} \mathrm{O}$ & $0.71 \%$ \\
\hline
\end{tabular}

Table 2: Major components of clay bricks (Osarenmwinda and Abel, 2014)

\begin{tabular}{ll}
\hline Oxide & Weight \% \\
\hline $\mathrm{CaO}$ & $0.72 \%$ \\
$\mathrm{Fe}_{2} \mathrm{O}_{3}$ & $11.8 \%$ \\
$\mathrm{SiO}_{2}$ & $53.9 \%$ \\
$\mathrm{Al}_{2} \mathrm{O}_{3}$ & $17.75 \%$ \\
$\mathrm{MgO}$ & $0.6 \%$ \\
$\mathrm{ZnO}$ & $0.9 \%$ \\
$\mathrm{Na} 2$ & $0.8 \%$ \\
$\mathrm{MnO}$ & 0.03 \\
$\mathrm{Cr}_{2} \mathrm{O}_{3}$ & 0.04 \\
$\mathrm{~K}_{2} \mathrm{O}$ & $3.3 \%$ \\
\hline
\end{tabular}

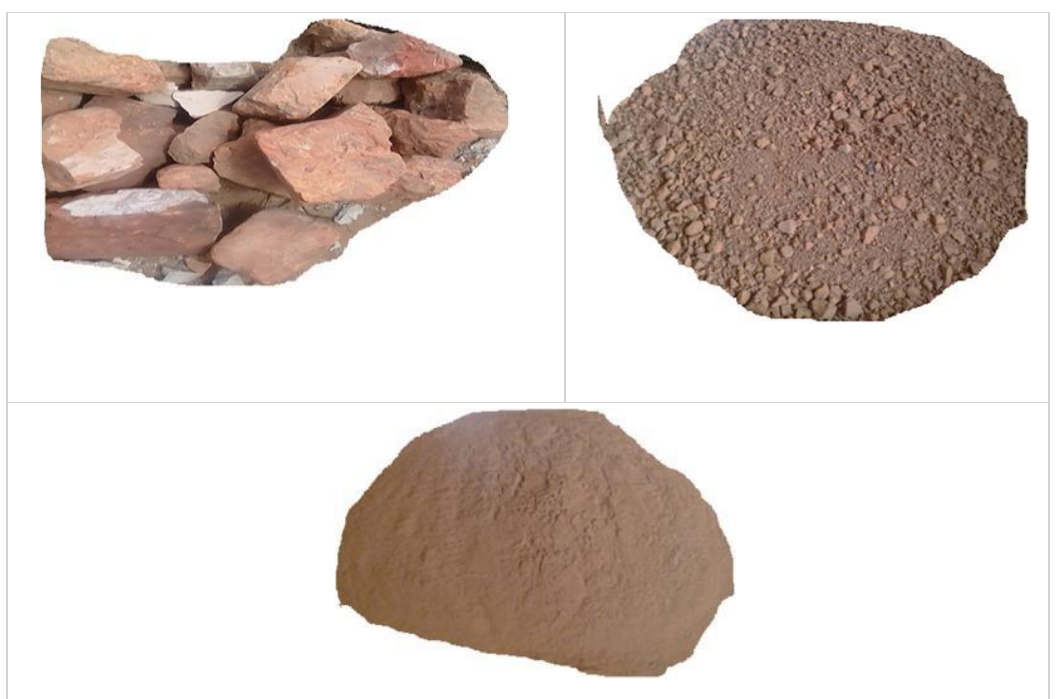

Figure 1: Waste bricks in crushed and powder forms

The locally obtained waste clay bricks, along with some fine and coarse aggregates were packed in bags and were transported from the Wilberforce Islands to the laboratory of Civil Engineering in Niger Delta University. The brick samples were crushed and ground to powder form, while the coarse aggregates were washed clean of mud traces. Finally, sieve analysis and specific gravity test on the samples were carried out after 12 hours of sun drying. The coarse and fine aggregates (max. size of 20mm) were uniformly graded in accordance with British Standards BS EN 12620:2013 (BSI, 2013). 


\subsection{Method}

The concrete samples were produced by batching by volume for compressive tests. A nominal mix ratio of 1:2:4 was adopted for concrete production using Portland cement. Produced concrete using this mix ratio was used as the control. The brick powder as a partial replacement for cement weights, i.e. a partial replacement of cement from 0 to 20 percent by weight was adopted. A water/cement ratio of 0.45 was adopted for the research work. Slump tests were conducted for every batch of concrete produced. $150 \mathrm{~mm} \times 150 \mathrm{~mm} \times 150 \mathrm{~mm}$ cube moulds were employed to be placeholders for the concrete, while the required tamping continued until adequate compaction on each cube mould was obtained, then the surface was finished with a trowel. The cubes remained stationary for 24 hours before they were demolded and placed in a curing tank. A total of 80 concrete cubes were cast. Table 3 shows the quantity of constituents required to produce 1 cubic metre of each sample used in this experiment using a water to cement ratio of 0.55 .

Table 3: Mix quantities for 1 cubic metre of samples

\begin{tabular}{lcccc}
\hline Mix name & $\begin{array}{c}\text { Cement } \\
(\mathbf{k g})\end{array}$ & $\begin{array}{c}\text { Brick powder } \\
(\mathbf{k g})\end{array}$ & $\begin{array}{c}\text { Fine aggregate } \\
(\mathbf{k g})\end{array}$ & $\begin{array}{c}\text { Coarse aggregate } \\
(\mathbf{k g})\end{array}$ \\
\hline CON (Control) & 300 & 0 & 690 & 1250 \\
SAMPLE 1 (2\% Cement replacement) & 294 & 6 & 690 & 1250 \\
SAMPLE 2 (5\% Cement replacement) & 285 & 15 & 690 & 1250 \\
SAMPLE 3 (7\% Cement replacement) & 279 & 21 & 690 & 1250 \\
SAMPLE 4 (8 \% Cement replacement) & 276 & 24 & 690 & 1250 \\
SAMPLE 5 (10\% Cement replacement) & 270 & 30 & 690 & 1250 \\
SAMPLE 6 (12\% Cement replacement) & 264 & 36 & 690 & 1250 \\
SAMPLE 7 (15\% Cement replacement) & 255 & 45 & 690 & 1250 \\
SAMPLE 8 (18\% Cement replacement) & 246 & 54 & 690 & 1250 \\
SAMPLE 9 (20\% Cement replacement) & 240 & 60 & 690 & 1250 \\
\hline
\end{tabular}

\subsubsection{Compressive Strength Test}

An Avery compression machine was used for the compression test experiment. The cast cubes are placed in the Avery compressive testing machine and loaded until their various compressive strengths were obtained. The cube strengths were obtained at 7, 14, 21, 28, 52 and 90 days. These tests performed were in accordance with the specifications in BS EN 12390-3:2019 (BSI, 2019a).

\subsubsection{Workability test}

The workability of the fresh concrete for all the samples was determined by the slump test. These tests were performed in accordance with the specifications in BS EN 12350-2:2019 (BSI, 2019b).

\subsection{Results and Discussion}

Experimental results showed that there was a marginal strength gain in concrete with a 10 percent partial replacement of cement with the waste clay bricks studied. An average of $11 \%$ increase in compressive strength was achieved with 10 percent partial replacement of cement with the waste clay bricks studied. However, as percentage replacement exceeds 10 percent, the positive impact of the pozzolan on the strength of concrete diminished. Interestingly, at 20 percent partial replacement of cement, there was no substantial strength loss in concrete, when compared with concrete made without partial replacement of cement. These results are similar to Bediako's (2018) findings. Bediako (2018) observed that the compressive strength performance of the control mortar, in his work, and mortars that contained 10 wt.\% and 20 wt.\% of Ground Waste Clay Bricks (GWCB) were 
statistically insignificant at 3, 7 and 28 days. In his work, the strength performance observed indicated that the optimum mortar mix was at Portland cement replacement with GWCB at $30 \mathrm{wt} . \%$. This mix was approximately $11 \%$ higher in strength at the curing periods when compared with the control mortar. The optimal replacement level which improved the strength of mortar much better than the control mortar could be attributed to the degree of pozzolanic reaction. Bediako (2018) also mentioned that the achievement of maximum strength means that the cement replacement content with a pozzolan is sufficient to convert cement hydration product i.e. calcium hydroxide into calcium silicate and aluminate hydrates which enhance strength properties.

This result of this work aligns with the findings of Bediako (2018). Bediako (2018) observed that the compressive strength performance of the control mortar, in his work, and mortars that contained 10 wt.\% and 20 wt. of Ground Waste Clay Bricks (GWCB) at 3, 7 and 28 days were statistically insignificant.

This work shows that despite the composition of local waste clay bricks used in this work, it is able to react cement hydration products i.e. calcium hydroxide, into calcium silicate and aluminate hydrates which enhance strength properties. Hence, a marginal increase in strength is observed. However, further work is required to understand the hydration process and chemistry of the reaction.

Figures 2 and 3 present a comparison of strength developed with the partial replacement of cement with waste clay bricks. It is also observed that while the long-term strengths of normal concrete did not significantly increase from its value at 28 days up to 90 days (See Figures 4 and 5), the strength of concrete made with waste clay bricks increased by 10 percent at 90 days, when compared to its 28 day strength.

Using least square regression approach, as shown in Equations 1, where $\mathrm{f}_{\mathrm{cu}}$ and $x$ are dependent and independent variables, respectively; $r_{i}$ is the residual; $\beta$ is a vector in the model function $f(x, \beta)$

$$
r_{i}=f_{c u}-f(x, \beta)
$$

And by minimizing the sum, $\mathrm{S}$, of the squared residual, $r_{\mathrm{i}}$, in Equation (2), we obtain the relationship in Equation (3)

$$
\begin{aligned}
& S=\sum r_{i}{ }^{2} \\
& f_{c u}=19.8 \operatorname{In}(x)+16.4
\end{aligned}
$$

Equation 3 represents the relationship between strength development and duration for a $10 \%$ partial replacement of sand with brick blocks. $\mathrm{f}_{\text {cu }}$ represents the compressive strength and $x$ represents duration in days. This equation predicts the compressive strength development between 0 to 90 days.

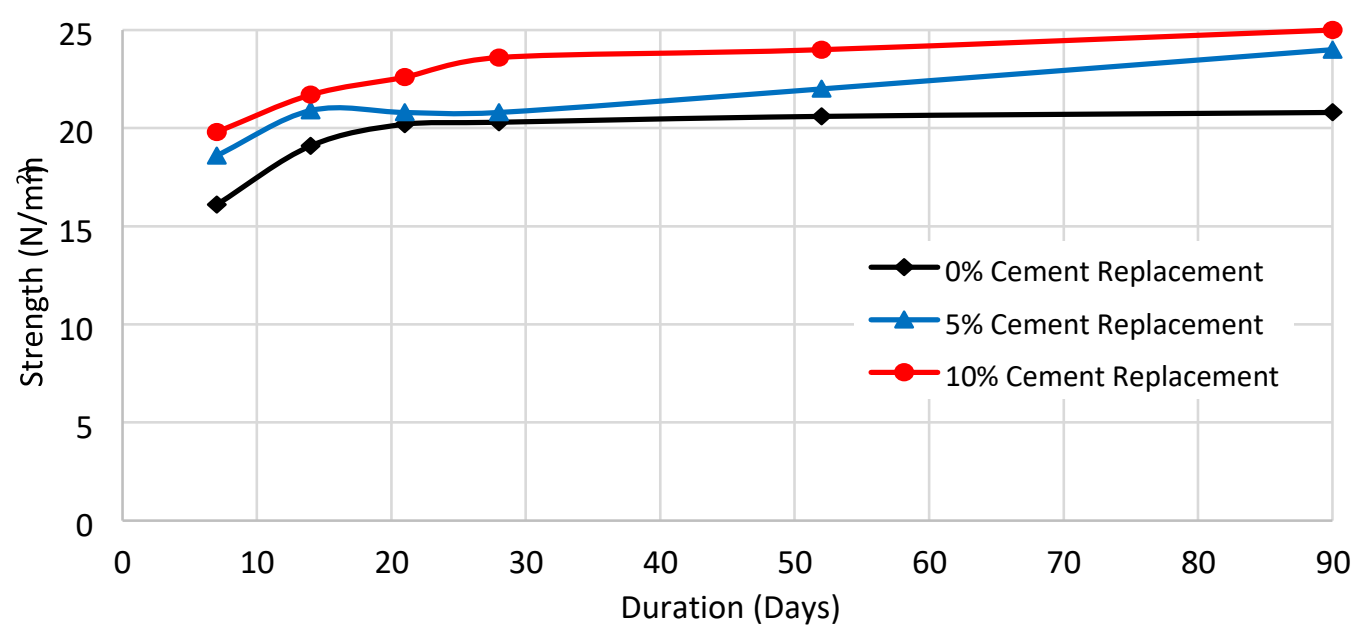

Figure 2: Strength development with $0-10$ percent partial replacement of cement with brick blocks 


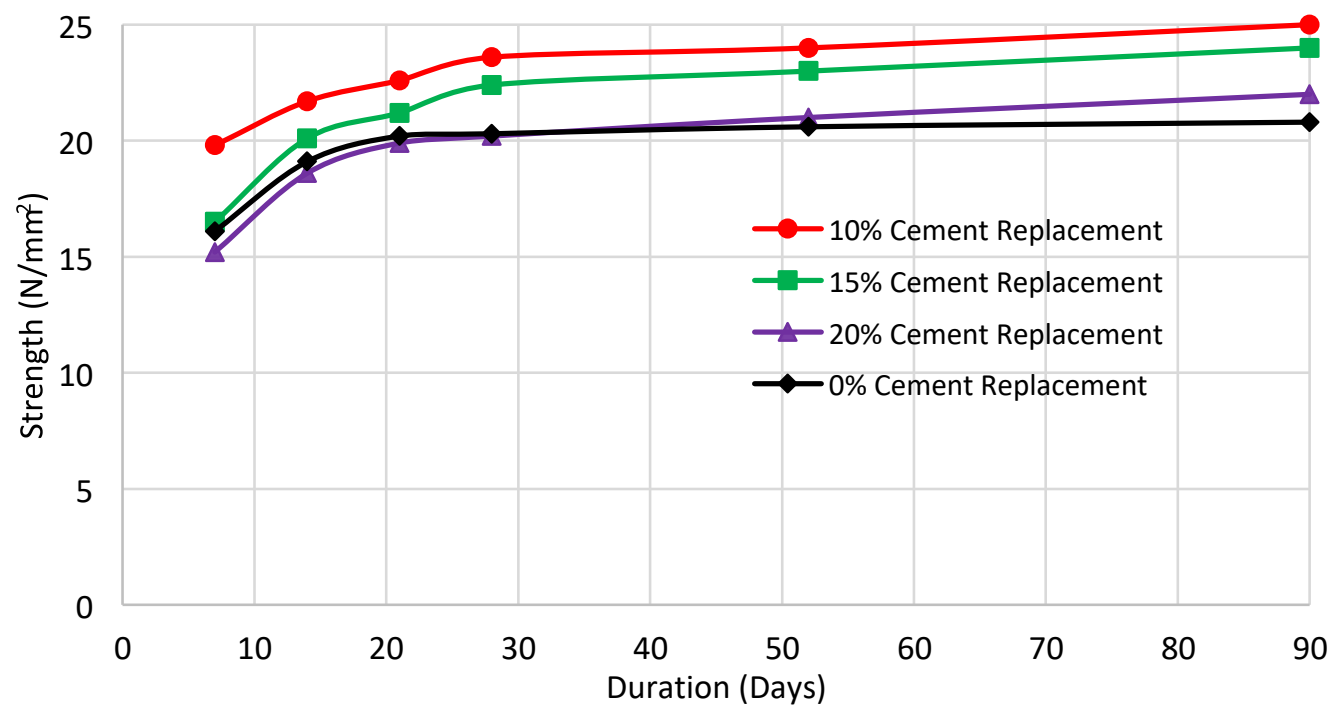

Figure 3: Strength development with $10-20$ percent partial replacement of cement with brick blocks

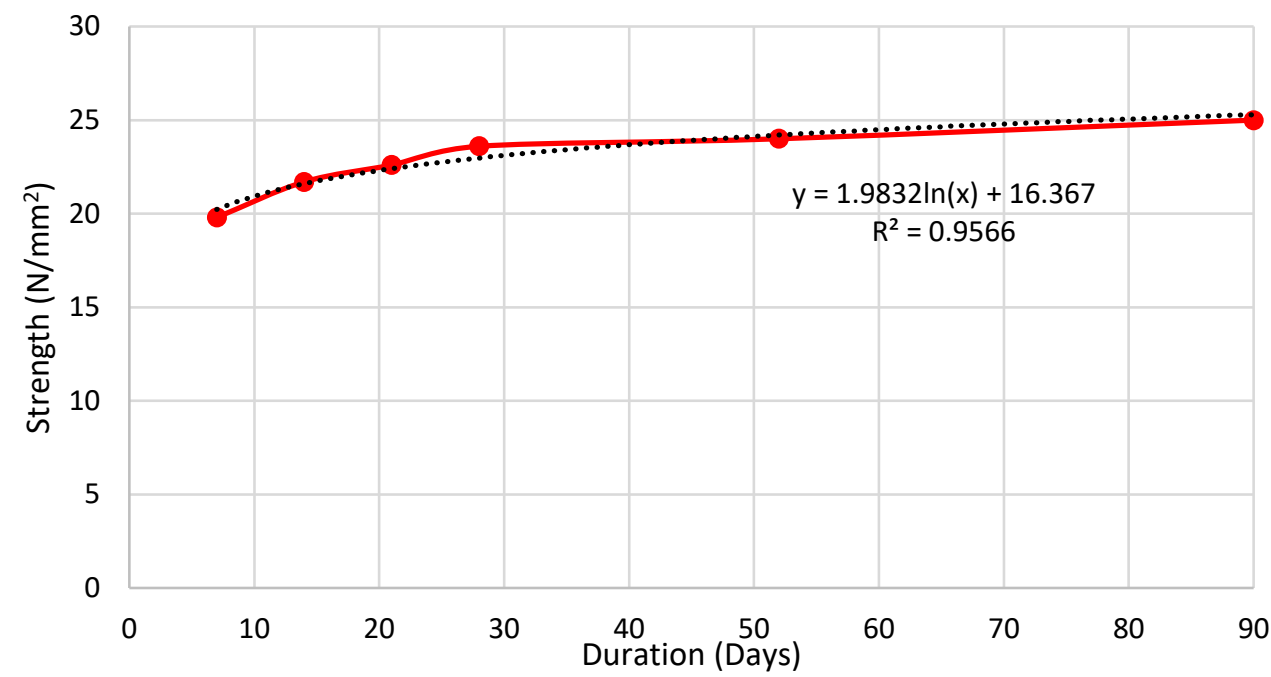

Figure 4: Regression curve showing relationship between strength and duration for $10 \%$ cement replacement with brick blocks

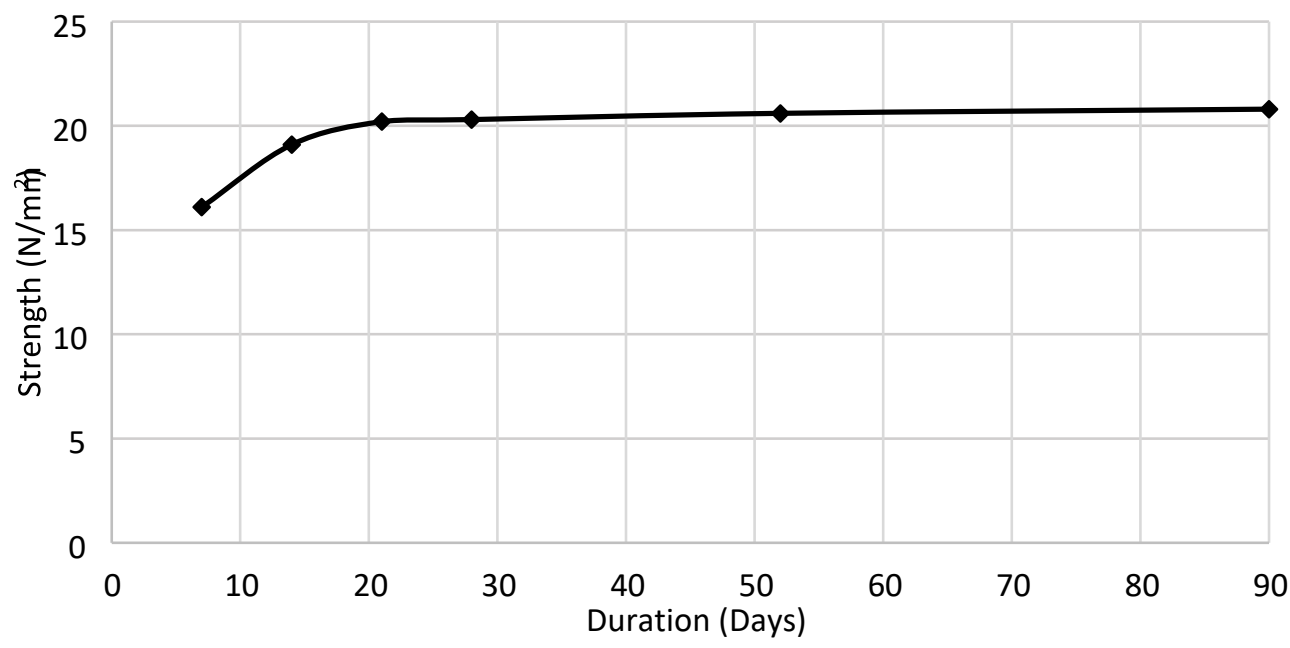

Figure 5: Regression curve showing relationship between strength and duration for $0 \%$ cement replacement with brick blocks 
Slump test results shown in Table 4 for the various concretes produced show that an increasing slump is achieved with an increasing cement replacement with brick blocks. This implies that with additional volume of fines from the brick blocks, consistency and workability increased in produced concrete. This result is indicative of a reduced water demand with increasing brick content.

Table 4: Slump test results

\begin{tabular}{ll}
\hline Percentage Replacement & Slump (in mm) \\
\hline $0 \%$ & 50 \\
$5 \%$ & 55 \\
$10 \%$ & 58 \\
$15 \%$ & 63 \\
$20 \%$ & 75 \\
\hline
\end{tabular}

\subsection{Conclusions}

Based on the outcome of the present investigation on the suitability of waste clay bricks as admixture in concrete works, the following conclusion can be drawn:

i. Waste clay brick studied possess sufficient pozzolanic properties and can be used effectively as a supplementary cementitious material.

ii. By replacing cement with waste clay bricks, in concrete production, a marginal increase in compressive strength can be achieved.

iii. Waste clay bricks increases the durability of concrete with marginal increase in compressive strength, even after 28 day

iv. An optimum strength of concrete is achieved with a 10 percent cement replacement with waste clay bricks.

v. The workability and constituency of concrete is improved with the addition of waste clay bricks to cement in concrete production.

It is recommended that a further study on the microscopic interaction of waste clay bricks and cement during hydration process be undertaken in order to fully understand the process of strength increase associated with the addition of bricks in concrete production.

\section{References}

ASTM (2015). ASTM C618-15 (2015). Standard Test for Coal Fly Ash and Raw or Calcined Natural Pozzolan for Use in Concrete, ASTM, International, West Conshoshocken PA.

Bahoria, B.V., Parbat, D.K. \& Naganaik, P.B. (2013). Replacement of natural sand in concrete by waste products: A state of art. J. Environ. Res. Dev. 7, 1651-1656

Bediako (2018). Pozzolanic potentials and hydration behavior of ground waste clay brick obtained from clamp-firing technology. Case Studies in Construction Materials 8, 1 -7

Bediako, M (2018). Pozzolanic potentials and hydration behavior of ground waste clay brick obtained from clamp-firing technology. Case Studies in Construction Materials, 8, 1 -7

Boniface, O.A and Appah, D (2015). Analysis of Nigerian Local Cement for Slurry Design in Oil and Gas Well Cementation. Academic Research International Vol. 5(4) 
BSI (2002). BS EN 1008:2002. Mixing water for concrete. Specification for sampling, testing and assessing the suitability of water, including water recovered from processes in the concrete industry, as mixing water for concrete. British Standards Institution, UK.

BSI (2011). BS EN 197-1:2011 Cement. Composition, specifications and conformity criteria for common cements. British Standards Institution, UK.

BSI (2013). BS EN 12620:2013: Aggregates for concrete. British Standards Institution, UK.

BSI (2019a). BS EN 12390-3:2019: Testing hardened concrete. Compressive strength of test specimens. British Standards Institution, UK.

BSI (2019b). BS EN 12350-2:2019. Testing fresh concrete. Slump test. British Standards Institution, UK

Detwiler, R., Bhatty, J.I and Bhattacharja, S., (1996). Supplementary Cementing Materials for Use in Blended Cements. Research and Development Bulletin Rd112t, Portland Cement Association, Skokie, Illinois, USA.

Devi, V.S. and Gnanavel, B.K. (2014). Properties of concrete manufactured using steel slag. Procedia Eng. 97, 95-104.

Elinwa, A.U. and Mahmood, Y.A (2002). Ash from timber waste as cement replacement material. Cement and Concrete Composites, vol. 24, no. 2, pp. 219-222.

Elinwa, U, S. P. Ejeh and Akpabio, I.O (2005). Using metakaolin to improve sawdust ash concrete. Concrete International, vol. 27, no. 11, pp. 49-52

Hasanpour, A. H. (2013). Effects of waste bricks powder of Gachsaran company as a pozzolanic material in concrete. Asian journal of civil engineering (BHRC) VOL. 14, NO.5 (2013), 755-763.

Hemraj R. and Kumavat, Y.N (2013). Feasibility Study of Partial Replacement of Cement and Sand in Mortar by Brick Waste Material. International Journal of Innovative Technology and Exploring Engineering, 17-20.

IEA, 2007. International Energy Agency,' Tracking Industrial Energy Efficiency and CO2 Emissions'. Paris, OECD/IEA. Available http://www.iea.org/publications/freepublications/.Mark

Imbabi, M.S., Carrigan, C. and McKenna, S., (2012). Trends and developments in green cement and concrete technology. Int. J. Sustain. Built Environ. 1, 194-216.

IPCC: 2006 IPCC Guidelines for National Greenhouse Gas Inventories, prepared by the National Greenhouse Gas Inventories Programme, edited by: Eggleston, H. S., Buendia, L., Miwa, K. Ngara, T., and Tanabe, K., IGES, Hayama, Japan, available at: http://www.ipccnggip.iges.or.jp/public/2006gl/index.html (last access: 21 May 2017), 2006

Miller, S.A, Horvath, A and Monteiro, Paulo J M (2016). Readily implementable techniques can cut annual $\mathrm{CO} 2$ emissions from the production of concrete by over $20 \%$. Environmental Research Letters, Volume 11, Number 7

Naik, T.R. (2008). Sustainability of concrete construction. Part. Period. Struct. Des. Constr. 13 (2), 98-103.

Nassar, R.U.D. and Soroushian, P. (2012). Strength and durability of recycled aggregate concrete containing milled glass as partial replacement for cement. Constr. Build. Mater. 29, 368-377.

Osarenmwinda, J. O. and Abel, C.P (2014) Performance Evaluation of Refractory Bricks produced from locally sourced Clay Materials. J. Appl. Sci. Environ. Manage, Vol. 18 (2) 151-15

Prabhu, G.G., J.H. Hyun, Y.Y. Kim (2014). Effects of foundry sand as a fine aggregate in concrete production. Constr. Build. Mater. 70, 514- 521. 
Rashed, A.M., (2014). Recycled waste glass as fine aggregate replacement in cementitious materials based on Portland cement. Constr. Build. Mater. 72, 340-357.

Ulukaya, S and Yüzer, N (2016). Assessment of pozzolanicity of clay bricks fired at different temperatures for use in repair mortar. Journal of Materials in Civil Engineering, Volume 28, Issue 8

Valcuende, M., Benito, F., Parra, C., Minano, I., (2015). Shrinkage of self-compacting concrete made with blast furnace slag as fine aggregate. Constr. Build. Mater. 76, 1-9.

Yahaya, M.D. (2009). Physico-Chemical Classification of Nigerian Cement. AU J.T. 12(3): 164-174

\section{Cite this article as:}

Nwankwo E. and John A. T., 2019. Strength and Workability Assessment of Concrete Produced by Partial Replacement of Cement with Waste Clay Bricks. Nigerian Journal of Environmental Sciences and Technology, 3(2), pp. 352-360. https://doi.org/10.36263/nijest.2019.02.0137 